\title{
Salt marsh surface survives true-to-scale simulated storm surges
}

Spencer $\mathrm{T}^{1}$, Möller $\mathrm{I}^{1,2}$, Rupprecht $\mathrm{F}^{3}$, Bouma $\mathrm{TJ}^{4}$, van Wesenbeeck BK ${ }^{5,6}$, Kudella $M^{7}$, Paul $M^{7}$, Jensen $K^{3}$, Wolters $G^{5}$, Miranda-Lange $M^{7}$, Schimmels $S^{7}$.

${ }^{1}$ Cambridge Coastal Research Unit, Department of Geography, University of

Cambridge, Downing Place, Cambridge CB2 3EN, UK

${ }^{2}$ Fitzwilliam College, Storey's Way, Cambridge CB3 0DG, UK

${ }^{3}$ Applied Plant Ecology, Biocenter Klein Flottbek, University of Hamburg,

Ohnhorststr. 18, 22609 Hamburg, Germany

${ }^{4}$ Yerseke Spatial Ecology, Netherlands Institute for Sea Research (NIOZ),

Korringaweg 7, 4401 NT Yerseke, The Netherlands

${ }^{5}$ Deltares, Rotterdamseweg 185, 2629 HD Delft, The Netherlands

${ }^{6}$ Department of Hydraulic Engineering, Delft University of Technology, P.O. Box

5048, 2600 GA Delft, The Netherlands

${ }^{7}$ Forschungszentrum Küste (FZK), Merkurstr. 11, 30419 Hannover, Germany

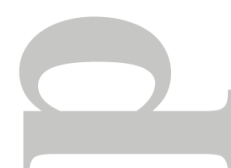

This article has been accepted for publication and undergone full peer review but has not been through the copyediting, typesetting, pagination and proofreading process, which may lead to differences between this version and the Version of Record. Please cite this article as doi: $10.1002 /$ esp.3867

This article is protected by copyright. All rights reserved. 


\section{Abstract}

A full-scale controlled experiment was conducted on an excavated and reassembled coastal wetland surface, typical of floristically diverse NW European saltmarsh. The experiment was undertaken with true-to-scale water depths and waves in a large wave flume, in order to assess the impact of storm surge conditions on marsh surface soils, initially with three different plant species and then when this marsh canopy had been mowed. The data presented suggests a high biogeomorphological resilience of salt marshes to vertical sediment removal, with less than $0.6 \mathrm{~cm}$ average vertical lowering in response to a sequence of simulated storm surge conditions. Both organic matter content and plant species exerted an important influence on both the variability and degree of soil surface stability, with surfaces covered by a flattened canopy of the salt marsh grass Puccinellia experiencing a lower and less variable elevation loss than those characterized by Elymus or Atriplex that exhibited considerable physical damage through stem folding and breakage.

Keywords Coastal wetland, surface elevation change, wetland soil stability, wave energy dissipation, wave flume experiment 


\section{Introduction}

Saltmarshes - distinctively vegetated, near-horizontal platforms sitting high in the tidal frame - have recently been re-evaluated in terms of the range of ecological services that they can provide on low-lying sedimentary coasts. One important service is that of hazard regulation through their role in water storage and wave energy dissipation, thus reducing damage to landward lying sea defences and flood risk to coastal communities and assets (and reducing the costs of flood defence structures around such resources) (Gedan et al., 2011). Long-term field monitoring programmes on NW European marshes, to establish general principles of wave energy dissipation in the face of multi-factorial combinations of tidal height; wave height, direction and duration; and varying marsh surface topography have established the importance of the ratio between significant wave height and overmarsh water depth as a key control on the efficacy of the dissipation process (Möller, 2006). Furthermore, it has been argued that, in NW Europe, deposition rates are generally proportional to the depth of water inundating the marsh platform (Allen, 2000) and that, on eastern seaboard USA Spartina alterniflora marshes, sedimentation rate is positively related to vegetation biomass which in turn is positively related to inundation depth (Morris, 2002; although plant growth is limited at lower boundaries by light and gas exchange and at upper boundaries either by salinity or competition (Bertness and Ellison, 1997()). Thus the 'the elevation of the marsh sedimentary platform ... [can be seen] ... as a crucial system state variable' (French, 2006, 120) and explains the considerable research interest (e.g. Fagherazzi et al., 2012) in the relations between surface elevation; sediment supply and sediment sequestration; and saltmarsh hydrodynamics, particularly in the context of 
changing water depths and wave climates with accelerated sea-level rise and potential changes in storm magnitudes and frequencies.

The literature on both contemporary and predicted near-future marsh surface responses to environmental forcing tends to be divided between discussions of the importance of storm-driven sedimentation in micro-tidal systems versus the role of surface elevation - flooding frequency relations, and responses to longer-term sea level rise, in meso- to macro-tidal systems (e.g. Allen, 2000; Kirwan and Guntenspergen, 2010). There are relatively few studies which consider the potential importance of decadal fluctuations in sea level in relation to surface change (but see French, 2006) or the role of decadal variations in storminess (e.g. Bartholdy et al., 2004) in driving inter-decadal variations in surface elevation change. Furthermore, Schuerch et al. (2012) argue, from a case study of historical saltmarsh sedimentation in the southern North Sea, that such temporal variability is likely to show a variable signature. In low marshes (high inundation frequency) accretion rates will primarily reflect storm magnitude whereas in high marsh (low inundation frequency) settings surfaces will be more responsive to changes in storm frequency. Considerations of the role of storm surge magnitude and frequency, however, raise the question as to whether there is a critical storm magnitude at which the marsh system collapses under extreme water depths and wave impacts.

Flume studies on the interaction between hydrodynamic processes and coastal vegetation tend to be hampered by scale effects as the water depths and waves that can be generated within flumes are often limited in depth and energy. Furthermore, most flumes are not built to accommodate sediments containing fine clays, so that investigations are limited to artificial bed materials. To the authors' knowledge, this is the first study to ever properly assess the impact of large waves on salt marsh 
elevation change under realistic storm inundation water depths. Salt marsh surface stability is inferred from measurements of marsh surface elevation change over a series of successive experimental runs of increasing wave-generated bed shear stress. Our results also report on the differences in soil surface response for soils under three different salt marsh species and for a 'mowed' marsh surface, a mimic for a marsh grazed by large herbivores.

\section{Methods and experimental design}

Experiments were conducted in the Large Wave Flume (Grosser Wellenkanal, GWK) of Forschungszentrum Küste (FZK) in Hannover, Germany. At 310 m long, 5 m wide and $7 \mathrm{~m}$ deep, the GWK facility is the world's largest freely accessible wave tank. The $39.44 \mathrm{~m}$ long vegetated test section $\left(\mathrm{ca} 180 \mathrm{~m}^{2}\right)$ was emplaced over a $1.2 \mathrm{~m}$ high, geotextile-covered sand base, $108 \mathrm{~m}$ from the wave paddle and illuminated by 60 flume wall-mounted lamps (GE $750 \mathrm{~W} 400 \mathrm{~V}$ PSL or equivalent) during construction and during the experimental runs. A flat concrete surface and ramped concrete slope was constructed at both the front and rear end of the test section to allow waves to shoal and/or break (Figure 1A). The design of the experimental setup was aimed at keeping wave reflection at the start and end of the vegetated test section at a minimum (see Möller et al., 2014). To construct the test section, $210 \mathrm{~m}^{2}$ of vegetated sediment was extracted, in $1.2 \times 0.8 \mathrm{~m} \times 0.3 \mathrm{~m}$ blocks, from a natural saltmarsh on the mainland coast of Eastern Frisia, German Wadden Sea $\left(53^{\circ} 42.754\right.$ $\left.\mathrm{N} ; 07^{\circ} 52.963 \mathrm{E}\right)$ in June 2012 . The vegetation was characterized by a mixed canopy of Elymus athericus (Elymus), Puccinellia maritima (Puccinellia), and Atriplex prostrata (Atriplex), typical of southern North Sea marsh plant communities at mid to high positions on the intertidal profile. Blocks were lifted by mechanical digger and 
placed on a wooden pallet, lined with a plastic sheet covered by a layer of geotextile. As the experiment could not be scheduled prior to autumn 2013, the marsh blocks were stored outdoors, with active management for temperature and moisture variations and herbivory, for 14 months. During this time, die-back of vegetation on some of the marsh blocks covered with Puccinellia facilitated the germination of dormant seeds of Atriplex. The individuals of this annual herbaceous species were left in situ as they represent a third salt marsh species common to NW European marshes and one which typically colonizes sites following surface disturbance. For marsh construction, individual blocks were moved into the flume by forklift truck, separated from their pallet, manoeuvred into position and finally keyed to each neighbouring block using marsh clay excavated from the field site as sealant (Figure 1B).

Immediately prior to exposure of the marsh blocks to varying levels of submergence and wave energy, soil characteristics were compared between the two main species, Elymus and Puccinellia, as well as between the marsh blocks in the flume and the marsh surface in the field, adjacent to the excavation site. Samples were extracted from $n=10$ and $n=20$ randomly selected marsh blocks containing Puccinellia and Elymus species respectively. In the field, samples were collected at random adjacent to the excavation site, but away from any potential disturbance caused by excavation activities. Samples were extracted from the top $3 \mathrm{~cm}$ of the soil using a plastic syringe and, acquired in this way, yielded a known volume $(20 \mathrm{ml})$, allowing bulk density (dry weight / volume), as well as particle size and total organic matter contents to be determined. Particle size was determined using a Malvern Mastersizer instrument in 0.5 phi interval bins, from -0.5 to 15.5 phi. Laser diffractometry methods have been shown to provide comparable results to previously 
accepted methods of particle size analysis, for example, pipette analysis (Eshel et al., 2004). Total organic matter was determined by loss-on-ignition (transferring samples to a muffle furnace and heating them to $400^{\circ} \mathrm{C}$ for at least six hours (overnight), after which the furnace temperature was reduced to $\sim 100^{\circ} \mathrm{C}$ upon which samples were allowed to cool in a desiccator and re-weighed).

Once the marsh fabric had been assembled and soil samples extracted, the flume was filled with freshwater. Wave experiments were run over five 'treatment periods' (hereafter referred to as 'treatments'), with a series of wave runs per 'treatment'. Experimental runs were conducted under either 1.0 or $2.0 \mathrm{~m}$ water depths above the vegetated soil surface and exposed to wave conditions that generated a progressively increasing level of expected bed shear stress throughout the run sequence. These inundation depths correspond to 1 in 10 year return events for marshes along the North Sea coast. On the North Norfolk coast, E. England, a storm surge event that inundates the permanently vegetated marsh platform by $2.0 \mathrm{~m}$ will have a still water level of ca. 4.4 m ODN (where 0.0 ODN approximates to mean sea level) (Steers et al., 1979). Estimates of extreme water level probabilities give a return period for such a water level as the 1 in 10 year event (Environment Agency, 2011); between 1953 and 2013, 6 surge events with a still water level > 4.5 m ODN were recorded at the Immingham tide gauge (Spencer et al., 2015). On the island of Sylt, German Wadden Sea, a + 2.0 m level over upper / mid marsh surfaces (3.39 m NN, Hoernum tide gauge) has a return period of ca. 9.5 years; during the period of record (1936-2007) 10 events >= 3.39 m NN have occurred (M. Schuerch, pers. comm., 2015). Seven different wave heights $\left(H_{m 0}: 0.1,0.2,0.3,0.4,0.6,0.8\right.$ and 0.9 m) were simulated. These simulations were chosen to replicate those commonly experienced on UK east coast salt marsh margins (Möller and Spencer, 2002), as 
well as the equivalent wave conditions occurring inshore under the water depths observed during storm surges (Spencer et al., 2015). Irregular waves ( $n \geq 1000)$ were generated using a JONSWAP spectrum with a peak enhancement factor of 3.3, followed by a regular wave run $(n \geq 100)$. The sequencing of each wave spectrum followed by regular waves was chosen to allow the dissipation of both irregular and regular waves to be measured over the test section at increasing energy levels (a more detailed description of wave measurement methods and results of the wave dissipation measurements are reported in Möller et al., 2014). At peak wave periods of between 1.5 and 6.2 seconds, each wave run lasted between 30 and 103 minutes. After each two days of treatments, during which 10 to 12 runs were completed, the flume was drained to allow plants to acquire oxygen. The full experimental run sequence, including the days on which the test section was drained, was carried out over a period of 16 days (Table 1). In the first set of wave runs of increasing bed stress levels, treatments A-D were conducted with an initially intact vegetation canopy. Prior to the second sequence of increasing bed stress conditions (treatment E), the saltmarsh canopy was 'mowed', by clipping the vegetation to the level of the soil surface with hand-held shears. When necessary, all floating organic debris was removed using a net $(1 \mathrm{~cm}$ mesh size) at the end of each wave run. In addition, accumulated vegetation debris to the rear of test section was retrieved after flume drainage.

In order to assess surface elevation change, a movable access platform was lowered into the flume over the vegetated section. The platform was then used to sequentially occupy six cross-flume positions. These were $2.3,9.1,14.5,19.8,29.6$, and $36.1 \mathrm{~m}$ from the leading (i.e. nearest the wave paddle) marsh edge (Figure 1). At each position, the platform was located $30 \mathrm{~cm}$ above the soil surface and 
temporarily keyed into a series of precision-fixed basal slots, with a horizontal and vertical relocation accuracy of $\pm 1 \mathrm{~mm}$ (as determined by measuring the platform position prior to each set of measurements against fixed markers on the flume wall). A series of 20 pins used for SET instruments (Cahoon et al., 2002) were lowered vertically onto the soil surface through apertures in a horizontal bar permanently fixed to one side of the platform (Figure 2). This created a total of six cross-flume profiles of surface elevation at a horizontal sampling interval of $20 \mathrm{~cm}$, starting at a distance of $45.2 \mathrm{~cm}$ from the southern flume wall. At platform position one only, the first pin position was at $74.8 \mathrm{~cm}$ from the flume wall. As a result, the last pin fell onto the $50 \mathrm{~cm}$ wide gravel walkway constructed for access along the northern flume wall and was not included in the measurements. This thus left a total of $N=(6 \times 20)-1=$ 119 pin measurements that were used for further analysis.

\section{Results}

\section{Soil characteristics by species type and effects of excavation}

Our results showed no statistically significant difference in median particle size $\left(D_{50}\right)$ and \% organic matter content between Puccinellia soil samples $(\mathrm{N}=10)$ and Elymus soils $(\mathrm{N}=20)$ in the flume at a confidence level of $p=0.05$ (Mann-Whitney $U$ test; Figure 3a). In the samples taken in the field, there was no statistically significant difference between the soils under these two species in terms of either median particle size $\left(D_{50}\right)$, \% organic matter content or bulk density.

Although excavation did not affect either grain size $\left(D_{50}\right)$ or soil bulk density, the treatment of the blocks led to a significant $(p<0.01)$ reduction in organic matter content under Elymus over the time period between field extraction and deployment 
in the flume. Whilst bulk density decreased under Puccinellia as a result of the excavation and storage of the marsh blocks (Figure 3b), this reduction was not statistically significant (at the $p \leq 0.5$ level). The excavation did, however, lead to a statistically significant reduction in median grain size $\left(D_{50}\right)$ under Puccinellia $(p \leq$ 0.01) (Figure 3c). However, it should be noted that smaller scale wave flume experiments elsewhere have shown no significant correlation between erosion (weight loss in cores placed in a flume) and changing sediment size characteristics in the silt-size range, materials similar to those used here (Feagin et al., 2009).

\section{Soil elevation change by wave run treatment}

Soil elevation change at any one pin location ranged from -5.2 to $+2.8 \mathrm{~cm}$ for beforeand-after comparisons over individual wave run treatments (Table 2, A to E) and from -5.8 to $+4.7 \mathrm{~cm}$ over the period of all wave run treatments (Table 2, F). None of the six cross-flume transects showed a consistent spatial pattern of elevation change with respect to pin distance from flume wall (i.e. no discernible flume side wall effect) or specific experimental run sequence. Figure 4 summarises elevation change observed across the entire test section (i.e. aggregated for the six cross-flume transects; Figure 1) per treatment (A to $E$ ) and over all treatments $(F)$. Elevation change was highly variable and not normally distributed. Whilst elevation change was small, it was significantly different from zero, with median (mean) change of $0.20(-0.17),--0.10(-0.19)$, and $-0.10(-0.15) \mathrm{cm})$ for treatments $A, D$, and $E$ respectively, as well as over the period of the entire experiment $(-0.50(-0.58) \mathrm{cm} ; \mathrm{F})$ (Table 2). 
Figure 5 shows summary statistics for elevation changes per platform position (see Figure 1 for platform positions) and per wave run treatment (A: post-initial wetting to first exposure, B: first to second exposure, C: second to third exposure, D: third to fourth exposure, and E: fourth exposure to post-mowing), as well as over the entire duration of the experiment ( $F$ : post-initial wetting to post-mowing).

\section{Soil elevation change by surface cover type and wave run treatment}

The influence of surface cover type around the pin (visual observations to within +/$10 \mathrm{~cm}$ around each pin location) on surface elevation change was analysed. Pins that fell on the border between individual marsh blocks (and hence on sealant soil rather than original block materials) or near which the surface cover was a mixture of plant types were not included in the analysis. Out of the total of 119 pin measurements, this resulted in 35 pin measurements under Elymus cover (at least three pins from each cross-flume transect), 19 measurements under Puccinellia (at least one on each transect), 14 under Atriplex (at least two on each transect); and 8 on bare surface (not sealant soil) (five pins from transect 6, one from transect 4, and two from transect 3).

For all surface cover types and all treatments, surface elevation change is summarised in Figure 6 and the statistical significance of the mean elevation change being different from zero was tested (one-sample t-test or Wilcoxon test (for nongaussian distributions), $\mathrm{p} \leq 0.05)$. For Atriplex, surface elevation change was statistically significantly different from zero for the third treatment $(\mathrm{C})$ only and for the whole experiment (F). For Puccinellia, significant change occurred only for the fourth run sequence (D) and for the whole experimental period (F). For Elymus, surface 
elevation change was significantly different only for the last experimental treatment (E) and for the period of the whole experiment $(F)(p \leq 0.05)$ and marginally significant for treatment $(B)(p=0.05)$. For bare soil, changes were significantly different from zero only for the whole experimental period $(F)$.

For individual wave treatments, only the third treatment $(\mathrm{C})$ and the whole experiment $(F)$ showed statistically significant differences in elevation change between surface cover types as a whole $(p<0.05)$ (Table 3$)$. For surface elevation change recorded over the duration of the entire experiment (i.e. post-wetting to postmowing elevation measurements), there was a significant difference between surface elevation change at pins with a surface cover of Puccinellia and, respectively, Elymus, Atriplex, and bare soil ( $p \leq 0.02$ ) (Table 3, F). No statistically significant difference was found between surface elevation change under Atriplex compared to that under Elymus, or between either of those two species and bare soil (Table 3, F).

\section{Discussion}

Empirical evidence for storm impacts on coastal wetland elevations and surface stability is largely opportunistic and anecdotal, although developments in field survey technologies (e.g. Real Time Kinematic (RTK) determinations of elevation (Gittman et al., 2014)) and standardized elevation measurements (e.g. the Surface Elevation Table - Marker Horizon (SET-MH) network (Webb et al., 2013)) are beginning to provide the cm-scale accuracy required for quantitative assessments. The range of reported impacts is wide: storm surges have been shown to cause sediment 
deposition, erosion, compaction and the thinning and removal of vegetative canopies in coastal wetlands. Furthermore, surface elevation change may be determined by storm-driven changes in subsurface processes. Thus substrates may catastrophically collapse with tree and root mortality consequent on canopy destruction by storms or, conversely, gain elevation from root and vegetation growth following storm-generated sedimentation or freshwater flushing of coastal sediments (Cahoon, 2006).

In NW Europe, observations suggest a high degree of surface stability under storm surge water level and associated wave impacts. In the aftermath of the 1953 storm surge, Steers remarked that 'natural salt marshes suffered not at all' (Steers, 1953, 287). Equally, the storm surge of January 1978 flooded the back-barrier marshes at Scolt Head Island to a depth of 2. $2-2.5 \mathrm{~m}$, but 'marsh surfaces appeared remarkably unaffected by the surge, both at Scolt and elsewhere on the Norfolk coast, though a great deal of dead vegetation was clearly removed from them to form the drift lines' (Steers et al., 1979, 202). In the same area, 'there appeared to be very little erosion of saltmarsh surfaces' (Spencer et al., 2015, 137) as a result of the storm surge of 5 December 2013. The results of this experiment quantitatively confirm these anecdotal observations of marsh platform surface stability. Although the variability of elevation change across the test section was an order of magnitude higher $(+/-6 \mathrm{~cm})$ than the mean surface elevation change recorded $(<0.6 \mathrm{~cm})$, overall median elevation change was statistically significantly different from zero. While wave dissipation over the test section was significant $(>15 \%$ for waves $>0.3$ m) (Möller et al., 2014), there was no down--flume spatial trend in surface elevation change (Figure 5), suggesting that the front and back end of the test section were not affected by additional turbulence or wave reflection. The magnitude of elevation 
loss was small given that the water depth and wave conditions simulated were typical of storm surge conditions (i.e. waves of up to $1 \mathrm{~m}$ in height in $2 \mathrm{~m}$ water depth); evidence from the 2013 high magnitude storm surge in North Norfolk, UK, suggests that water depths and wave conditions during that event were comparable to those in this experiment (Spencer et al., 2014).

In the context of concerns over marsh loss due to a potential increase in the frequency of high energy storm events, these results suggest that the prime concern must be one over the frontal erosion of these platforms, either through marsh edge cliff retreat (Möller and Spencer, 2002) or creek network expansion (Kirwan and Murray, 2007), rather than through any loss of sediment from their surfaces. Indeed, Feagin et al. (2009) observed that interior marsh surfaces are much less responsive to wave action than fringing margins. Recent modelling suggests that marsh edge retreat is promoted by strong winds and an active wave regime, further reinforced by wide mudflats and erodible marsh sediments (Mariotti and Fagherazzi, 2013; Mariotti and Carr, 2014). Overall, our limited ability to account quantitatively for such longterm shifts in i) marsh edge / tidal flat and ii) marsh edge / channel boundaries form one of the main knowledge gaps hampering application of salt marshes within coastal defence schemes (Bouma et al., 2014).

In terms of the sequencing of hydrodynamic energy treatments in this experiment, it is interesting to note that no individual wave treatment could be identified as causing more than $33 \%$ of the total mean elevation loss across all pin locations. The fact that elevation loss was significantly different from zero for the first, fourth and fifth treatments, with cumulatively greater average surface lowering $(-0.17,-0.19$, and $1.50 \mathrm{~cm})$ as well as for the entire experiment $(-0.58 \mathrm{~cm})$, however, suggests that the initial bed stress and the cumulative weakening of the bed towards the end of the 
experiment may have been key factors in explaining overall elevation loss. This pattern can be explained by the wave stress initially exceeding the shear strength of the soil surface, which had, at that point in time, been inundated only once for the first time in 15 months. Even small waves thus managed to remove material. After this initial soil loss, the soil remained stable until the test runs with the highest wave stress (fourth treatment) and the test runs over the mowed surface (fifth treatment).

A decrease in the variability of elevation change from the first $(-5.2$ to $+2.4 \mathrm{~cm})$ to the last $(-1.5$ to $+1.0 \mathrm{~cm})$ wave treatment was also apparent, suggesting that variations in surface characteristics had a greater influence on soil erosion at the start of the experiment than at the end. It is possible that, during the first treatment (A: top left plot, Figure 5), material was removed from the front, transported, and deposited onto the back of the test section, while for the second to fourth treatment no clear pattern of surface change emerged, and the last treatment appeared to cause most erosion at the front and the back of the test section. The reasons for the preferential erosion at the front and back of the test section during the mowed treatments are not clear as any edge effects are unlikely, given the distance of more than $3 \mathrm{~m}$ between the front and back of the test section and the first and last pin measurement bar positions respectively (Figure 1).

The third set of experimental runs (C), when maximum wave orbital velocity increased from 0.33 to $0.66 \mathrm{~m} \mathrm{~s}^{-1}$, showed a significant difference in surface elevation change between surfaces covered by Puccinellia and, respectively, those covered by Elymus and Atriplex (Figure 6). These differences in surface change coincided with a change in plant behaviour under wave motion reported by Möller et al. (2014). From treatment C, Puccinellia reconfigured in the flow to a flattened 'surface shielding' canopy close to the soil surface while Atriplex and Elymus 
experienced stem folding and breakage. It is hypothesized, therefore, that the latter response mode to wave motion provided less surface erosion protection than that provided by Puccinellia. The indication that surface stability varies between species has implications for the conservation and management of marshes and should be a key area of investigation for further research. In addition, attention should be given to the role of organic matter present in surface soils and the importance of carbon capture, both in relation to contemporary marsh surface dynamics (e.g. Feagin et al., 2009) and in the context of near-future changes associated with climate and sea level change (e.g. Mudd et al. 2009; Kirwan and Mudd, 2012). In relation to the species present in this study, Puccinellia and Atriplex generally exhibit low amounts of below ground biomass and shallow rooting in contrast to Elymus which reproduces clonally by rhizomes and has an extensive rooting system. Valery et al. (2004) have noted enhanced carbon trapping under, and increased litter production by, Elymus species. Formerly restricted to high marshes, Elymus began to progressively invade some NW European middle and low marshes from the 1990s (Van Wijnen and Bakker, 1997), suggesting a potential regional scale shift in marsh surface stability.

Mowing the test section clearly had greater effect on surface elevation response to wave impact for the locations where the measurement pins were positioned over exposed soil ('bare soil' category in Figure 6) than for soil that had been under any of the three species (Figure $6 \mathrm{E}$ ). This suggests that even when the surface canopy is removed during a high energy event, the soil is more stable due to the influence of the presence of vegetation on soil stability. By the time of the third (C) and fourth (D) treatment (i.e. the highest energy levels), surface elevation change under Puccinellia had become much more varied than under the earlier treatments. The patchy 
variations in density of Puccinellia stems, with a tendency to occur in 'clumps' may be one reason for the greater variability in elevation change under higher energy levels, as enhanced flow and soil loss has been reported by others for such 'clumped' vegetation arrangement (Bouma et al., 2007). By the fifth treatment (E), however, surface elevation change became generally less varied again, potentially reflecting the fact that mowing had resulted in a reduced influence of vegetation clumps.

\section{Conclusions}

Feagin et al. (2010) have called for controlled experiments to determine the effect of storms on coastal ecosystems. This paper reports on one such controlled experiment, the first of its kind to have attempted a full-scale simulation of storm surge conditions over a natural , floristically diverse north-west European salt marsh surface consisting of Elymus, Puccinellia, and Atriplex species. The effect of such conditions on the vegetation has been reported elsewhere (Möller et al., 2014) and those observations have suggested that, while marsh vegetation suffers significant damage through repeated flexing and ultimately breakage of plant stems, the marsh canopy continues to act as an efficient wave buffer, even at reduced canopy density/biomass. The results reported here add another dimension to the study of storm surge impacts on salt marshes. They demonstrate that:

(i) The marsh surface underneath the vegetation canopy experienced less than $0.6 \mathrm{~cm}$ average vertical lowering in response to a series of simulated storm surge conditions;

This article is protected by copyright. All rights reserved. 
(ii) This high degree of marsh surface stability is all the more surprising as the hydrodynamic stress generated in the flume was arguably more extreme than it would have been in a real surge, due to the prolonged time of freshwater submergence (two successive days, separated by one to two days of exposure, for 17 days);

(iii) Both organic matter content and plant species exerted an important influence on both the variability and degree of soil surface stability, with surfaces covered by Puccinellia that showed a high resilience to wave forcing experiencing a lower and less variable elevation loss than those covered by Elymus or Atriplex that exhibited considerable physical damage; and

(iv) In terms of increasing stress levels, soils under Atriplex experienced average elevation lowering that was significantly greater than zero (given the range of observed lowering) under lower threshold maximum wavegenerated orbital bed velocities $\left(0.66 \mathrm{~m} \mathrm{~s}^{-1}\right.$ or higher), followed by soils under Puccinellia (1.00 $\mathrm{m} \mathrm{s}^{-1}$ or higher) and then soils under Elymus (due to the high variability in surface lowering, average lowering only became significantly different from zero after mowing the vegetation and exposing soils to $0.89 \mathrm{~m} \mathrm{~s}^{-1}$ or higher orbital bed velocities).

As well as contributing to debates around the process and time-scale of recovery of salt marshes from extreme storm surge events, our results have implications for the management and conservation of salt marshes. Although the data presented here suggests a high geomorphological resilience of salt marshes to vertical sediment removal, it highlights that future research must now move to address more closely the three-dimensional connectivity between the marsh edge (arguably more 
susceptible to erosion) and the marsh surface, as well as the factors that determine the links between the type of vegetation growth, organic matter dynamics and marsh soil stability.

\section{Acknowledgements}

We thank all of the support staff at the Grosser Wellenkanal; Ben Evans, James Tempest, Kostas Milonidis, Chris Rolfe and Colin Edwards, Cambridge University; and Dennis Schulze, Hamburg University, for their invaluable logistical assistance. Fitzwilliam College, Cambridge supported the research time of IM. The work described in this publication was supported by the European Community's $7^{\text {th }}$ Framework Programme (Integrating Activity HYDRALAB IV, Contract No. 261529) and by a grant from The Isaac Newton Trust, Trinity College, Cambridge. We thank Mark Schuerch, Kiel University, for helpful insights into storm surge flooding on Sylt, Germany Wadden Sea. The authors have no conflicts of interest to declare. 


\section{References}

Allen JRL. 2000. Morphodynamics of Holocene saltmarshes: a review sketch from the Atlantic and Southern North Sea coasts of Europe. Quaternary Science Reviews 19 : 1155-1231. DOI: http://dx.doi.org/10.1016/S0277-3791(99)00034-7

Bartholdy J, Christiansen C, Kunzendorf H 2004. Long term variations in backbarrier salt marsh deposition in the Skallingen Peninsula - Danish Wadden Sea. Marine Geology 203 : 1-21. DOI: 10.1016/S0025-3227(03)00337-2

Bertness MD, Ellison AM 1997. Determinants of pattern in a New England salt Marsh plant community. Ecological Monographs 57 : 129-147. DOI: 10.2307/1942621

Bouma TJ, van Duren LA, Temmerman S, Claverie T, Blanco-Garcia A, Ysebaert T, Herman PMJ 2007. Spatial flow and sedimentation patterns within patches of epibenthic structures: combining field, flume and modelling experiments. Continental Shelf Research 27 : 1020-1045.DOI: 10.1016/j.csr.2005.12.019

Bouma TJ, van Belzen J, Balke T, Zhu Z, Airoldi L, Blight AJ, Davies AJ, Galvan C, Hawkins SJ, Hoggart SPG, Lara JL, Losada IJ, Maza M, Ondiviela B, Skov MW, Strain EM, Thompson RC, Yang S, Zanuttigh B, Zhang L, Herman PMJ. 2014. Identifying knowledge gaps hampering application of intertidal habitats in coastal protection: Opportunities \& steps to take. Coastal Engineering 87 : 147-157. DOI: 10.1016/coastaleng.2013.11.014

Cahoon DR. 2006. A review of major storm impacts on coastal wetland elevations. Estuaries and Coasts 29 : 889-898. DOI: 10.1007/BF02798648

Cahoon DR, Lynch JC, Perez BC, Segura B, Holland RD, Stelly C, Stephenson G, Hensel P. 2002. High-precision measurements of wetland sediment elevation: II. The 
rod surface elevation table. Journal of Sedimentary Research 72 : 734-739. DOI: $10.1306 / 020702720734$

Environment Agency 2011. Coastal flood boundary conditions for UK mainland and islands. Project: SC060064/TR2: Design Sea-Levels. Environment Agency, Bristol.

Eshel, G., Levy GJ, Mingelgrin U, Singer MJ. 2004. Critical evaluation of the use of laser diffraction for particle-size distribution analysis. Soil Science Society of America Journal 68 : 736-743. DOI : 10.2136/sssaj2004.0736

Fagherazzi S, Kirwan ML, Mudd SM, Guntenspergen GR, Temmerman S, D’Alpaos A, van de Koppel J, Rybczyk JM, Reyes E, Craft C, Clough J. 2012. Numerical models of salt marsh evolution: Ecological, geomorphic, and climatic factors. Review of Geophysics 50 : RG1002. DOI: 10.1029/2011RG000359

Feagin RA, Lozada-Bernard SM, Ravens TM, Möller I, Yeager K M, Baird AH. 2009. Does vegetation prevent wave erosion of salt marsh edges? Proceedings of the National Academy of Sciences of the United States of America 106 : 10109-13. DOI: 10.1073/pnas.0901297106Feagin RA, Mukherjee N, Shanker K, Baird AH, Cinner J, Kerr AM, Koedam N, Sridhar A, Arthur R, Jayatissa LP, Lo Seen D, Menon M, Rodriguez S, Shamsuddoha Md, Dahdouh-Guebas F. 2010. Shelter from the storm? Use and misuse of coastal vegetation bioshields for managing natural disasters. Conservation Letters 3 : 1-11. DOI i: 10.1111/j.1755-263X.2009.00087.x

French J, 2006. Tidal marsh sedimentation and resilience to environmental change: Exploratory modelling of tidal, sea-level and sediment supply forcing in predominantly allochthonous systems. Marine Geology 235 : 119-136. DOI: 10.1016/j.margeo.2006.10.009

This article is protected by copyright. All rights reserved. 
Gedan KB, Kirwan ML, Wolanski E, Barbier EB, Silliman BR. 2011. The present and future role of coastal wetland vegetation in protecting shorelines: answering recent challenges to the paradigm. Climatic Change 106 : 7-29. DOI: 10.1007/s10584-0100003-7

Gittman RK, Popowich AM, Bruno JF, Peterson CH. 2014. Marshes with and without sills protect estuarine shorelines from erosion better than bulkheads during a Category 1 hurricane. Ocean and Coastal Management 102 : 92-102. DOI: 10.1016/j.ocecoaman.2014.09.016

Kirwan ML, Guntenspergen GR. 2010. Influence of tidal range on the stability of coastal marshland, Journal of Geophysical Research: Earth Surface 115 : F02009, DOI: $10.1029 / 2009 J F 001400$

Kirwan ML, Mudd SM. 2012. Response of salt-marsh carbon accumulation to climate change. Nature 489 : 550-553. DOI: 10.1038/nature11440

Kirwan ML, Murray AB 2007. A coupled geomorphic and ecological model of tidal marsh evolution. Proceedings of the National Academy of Sciences of the United States of America 104 : 6118-6122. DOI: 10.1073/pnas.0700958104

Mariotti G, Carr J. 2014. Dual role of salt marsh retreat: Long-term loss and shortterm resilience, Water Resources Research 50 : 2963-2974, DOI: 10.1002/2013WR014676.

Mariotti G, Fagherazzi S. 2013. Critical width of tidal flats triggers marsh collapse in the absence of sea-level rise. Proceedings of the National Academy of Sciences of the United States of America 110 : 5353-5356. DOI: 10.1073/pnas.1219600110. 
Möller I. 2006. Quantifying saltmarsh vegetation and its effect on wave height dissipation: results from a UK east coast saltmarsh. Estuarine, Coastal and Shelf Science 69 : 337-351. DOI: 10.1016/j.ecss.2006.05.003

Möller I, Kudella M, Rupprecht F, Spencer T, Paul M, van Wesenbeeck BK, Wolters G, Jensen K, Bouma TJ, Miranda-Lange M, Schimmels S. 2014. Wave attenuation over coastal salt marshes under storm surge conditions. Nature Geoscience 7 : $727-$ 731. DOI: $10.1038 /$ ngeo2251

Möller I, Spencer T. 2002. Wave dissipation over macro-tidal saltmarshes: Effects of marsh edge typology and vegetation change. Journal of Coastal Research, Special Issue, 36 : 506-521.

Morris JT, Sundareshwar PV, Nietch CT, Kjerfve B, Cahoon DR. 2002. Responses of coastal wetlands to rising sea-level. Ecology $83: 2869-2877$. DOl: $10.2307 / 3072022$

Mudd SM, Howell SM, Morris JT. 2009. Impact of dynamic feedbacks between sedimentation, sea-level rise, and biomass production on near-surface marsh stratigraphy and carbon accumulation. Estuarine, Coastal and Shelf Science 82 : 377-389. DOI: 10.1016/j.ecss.2009.01.028

Schuerch M, Rapaglia J, Liebetrau V, Vafeidis A, Reise K. 2012. Salt marsh accretion and storm tide variation: an example from a barrier island in the North Sea. Estuaries and Coasts 35 : 486-500. DOI: 10.1007/s12237-011-9461-z

Spencer T, Brooks SM, Evans BR, Tempest JA, Möller I. 2015. Southern North Sea storm surge event of 5 December 2013: Water levels, waves and coastal impacts. Earth-Science Reviews 146, 120-145. DOI: 10.1016/j.earscirev.2015.04.002 
Spencer T, Brooks SM, Möller I, Evans BR. 2014. Where local matters : Impacts of a major North Sea storm surge. EOS (Transactions of the American Geophysical Union) 95 : 269-270. DOI: 10.1002/2014EO300002

Steers JA. 1953. The east coast floods. The Geographical Journal 119 : 280-295. DOI: $10.2307 / 1790640$

Steers JA, Stoddart DR, Bayliss-Smith TP, Spencer T, Durbridge P. 1979. The storm surge of 11 January 1978 on the east coast of England. The Geographical Journal 145 : 192-205. DOI: $10.2307 / 634386$

Valery L, Bouchard V, Lefeuvre J-C. 2004. Impact of the invasive native species Elymus athericus on carbon pools in a salt marsh. Wetlands 24 : 268-276. DOI: 10.1672/0277-5212(2004)024[0268:IOTINS]2.0.CO;2

Van Wijnen HJ, Bakker JP 1997. Long-term surface elevation change in salt marshes: A prediction of marsh response to future sea-level rise. Estuarine, Coastal and Shelf Science 52 : 381-390. DOI: 10.1006/ecss.2000.0744

Webb EL, Friess DA, Kraus KW, Cahoon DR, Guntrenspergen GR, Phelps J. 2013. A global standard for monitoring coastal wetland vulnerability to accelerated sea level rise. Nature Climate Change 3 : 458-465. DOI: 10.138/NCLIMATE1756

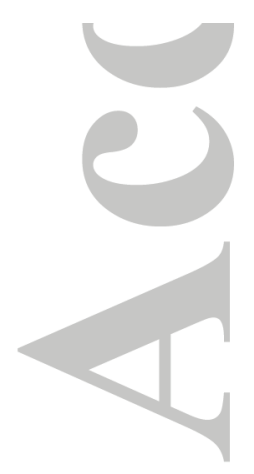

This article is protected by copyright. All rights reserved. 
Table 1: Number of wave runs and wave height, period, and maximum orbital velocity ranges for each of the experimental exposure periods, i.e. treatments (note: usually, each irregular wave run was followed by a corresponding regular wave run). Treatments were as follows:

A: post-initial wetting to first flume draining and marsh surface exposure, B: first to second exposure, C: second to third exposure, D: third to fourth exposure, and E: fourth exposure to post-mowing, as well as over the entire duration of the experiment (F: post-initial wetting to post-mowing).

\begin{tabular}{|c|c|c|l|l|l|l|l|l|l|}
\hline Treatment & $\begin{array}{l}\text { Day of } \\
\text { Surface } \\
\text { elevation } \\
\text { readings }\end{array}$ & \multicolumn{2}{|l|}{ Irregular wave runs $(\mathrm{n} \approx 1000$ waves) } & \multicolumn{3}{l|}{ Regular wave runs (n $\approx 100$ waves) } \\
\hline & & $\mathrm{n}$ & $\begin{array}{l}\mathrm{H}_{\mathrm{s}} \\
(\mathrm{cm})\end{array}$ & $\mathrm{T}_{\mathrm{p}}(\mathrm{s})$ & $\begin{array}{l}\mathrm{U}_{\max } \\
\left(\mathrm{m} \mathrm{s}^{-1}\right)\end{array}$ & $\mathrm{n}$ & $\mathrm{H}(\mathrm{cm})$ & $\mathrm{T}(\mathrm{s})$ & $\begin{array}{l}\mathrm{U}_{\max } \\
\left(\mathrm{m} \mathrm{s}^{-1}\right)\end{array}$ \\
\hline $\mathrm{A}$ & 1 & 3 & $11-21$ & $1.4-6.3$ & $0.01-0.15$ & 3 & $11-19$ & $1.5-2.9$ & $0.01-0.15$ \\
\hline $\mathrm{B}$ & 4 & 5 & $21-30$ & $2.1-3.7$ & $0.15-0.26$ & 5 & $18-30$ & $2.1-3.6$ & $0.15-0.26$ \\
\hline $\mathrm{C}$ & 8 & 5 & $39-60$ & $2.9-5.3$ & $0.29-0.61$ & 5 & $38-70$ & $2.9-5.1$ & $0.28-0.70$ \\
\hline $\mathrm{D}$ & 11 & 5 & $50-87$ & $3.4-6.3$ & $0.69-0.94$ & 6 & $45-113$ & $3.3-6.2$ & $0.62-1.16$ \\
\hline $\mathrm{E}^{*}$ & 16 & 6 & $39-78$ & $2.8-4.1$ & $0.29-0.69$ & 6 & $18-89$ & $2.1-4.1$ & $0.20-0.82$ \\
\hline $\mathrm{F}$ & All runs & 24 & $11-87$ & $1.4-6.3$ & $0.01-0.94$ & 25 & $11-113$ & $1.5-6.2$ & $0.01-1.16$ \\
\hline
\end{tabular}

*vegetation was mowed before treatment 'E'

This article is protected by copyright. All rights reserved. 
Table 2: Summary statistics for elevation changes $(\mathrm{cm}$; negative values indicate surface lowering, positive values indicate increases in surface elevation) observed over all pin locations over the first $(A)$ to last $(E)$ wave run treatment and over the period of all treatments $(F)$. (For treatment details see Table 1).

\begin{tabular}{|l|r|r|r|r|r|r|}
\hline & Minimum & Maximum & Mean & $\begin{array}{c}\text { Std. } \\
\text { Deviation }\end{array}$ & Median & Sig. (2-tailed) \\
\hline A & -5.2 & +2.4 & -0.17 & 0.74 & -0.20 & .003 \\
B & -1.2 & +2.8 & +0.02 & 0.51 & 0.00 & .214 \\
C & -2.5 & +2.2 & -0.09 & 0.62 & -0.10 & .058 \\
D & -2.1 & +1.6 & -0.19 & 0.55 & -0.10 & .000 \\
E & -1.5 & +1.0 & -0.15 & 0.44 & -0.10 & .001 \\
F & -5.8 & +4.7 & -0.58 & 1.01 & -0.50 & .000 \\
\hline
\end{tabular}

This article is protected by copyright. All rights reserved. 
Table 3: Statistical testing (Mann-Whitney U test, 2-tailed test) for difference between different surface cover type, before-after all wave runs (F, Figure 6$)$ and between sets of runs (A-E, Figure 6).

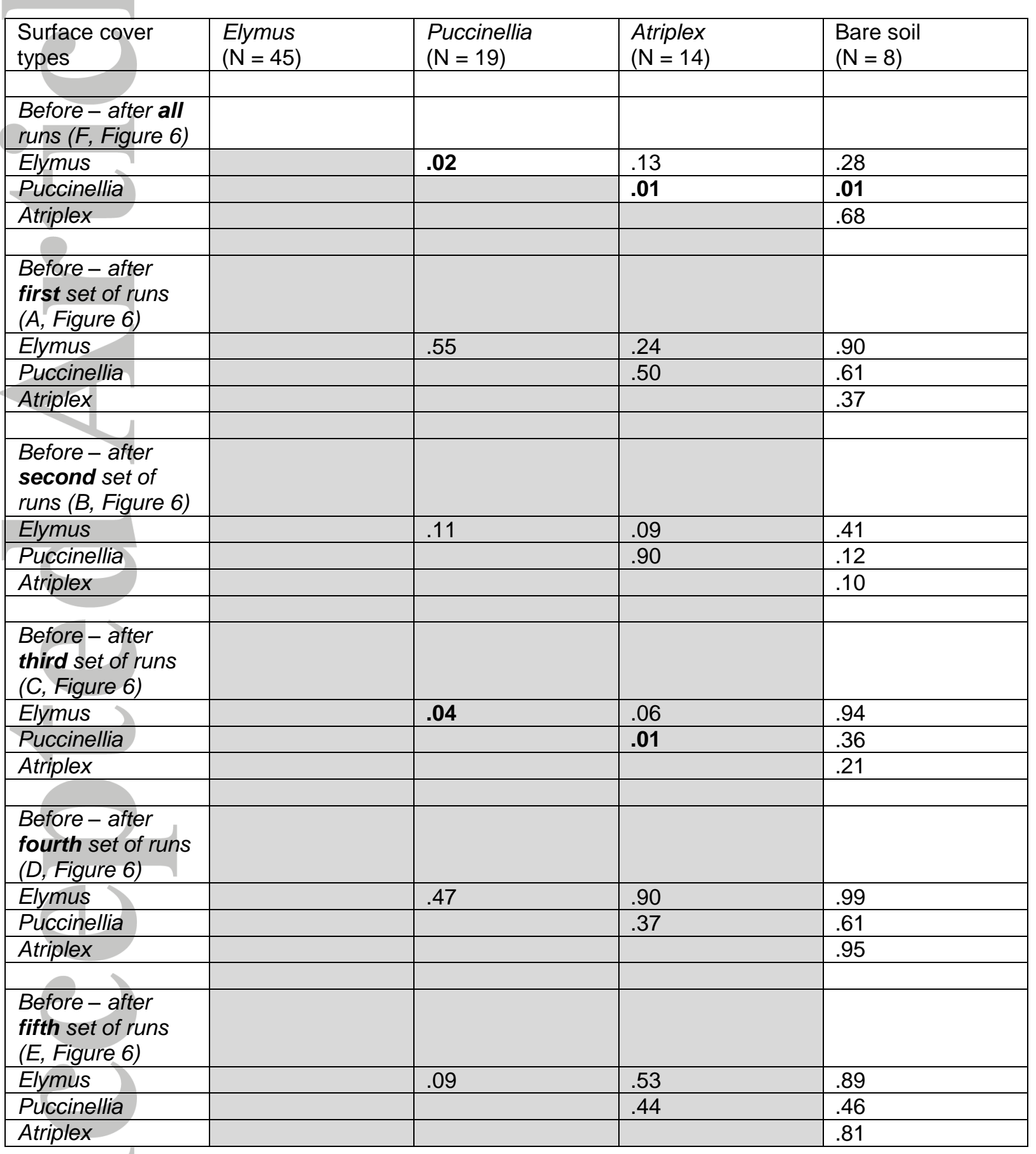

This article is protected by copyright. All rights reserved. 
A

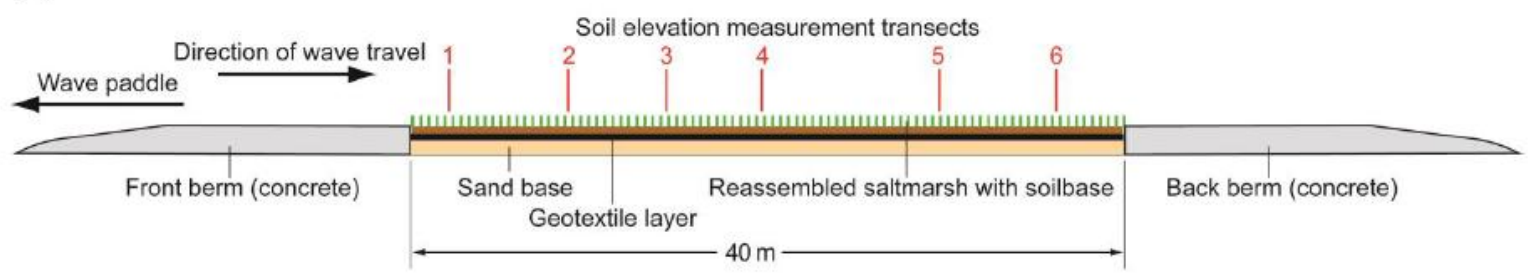

B

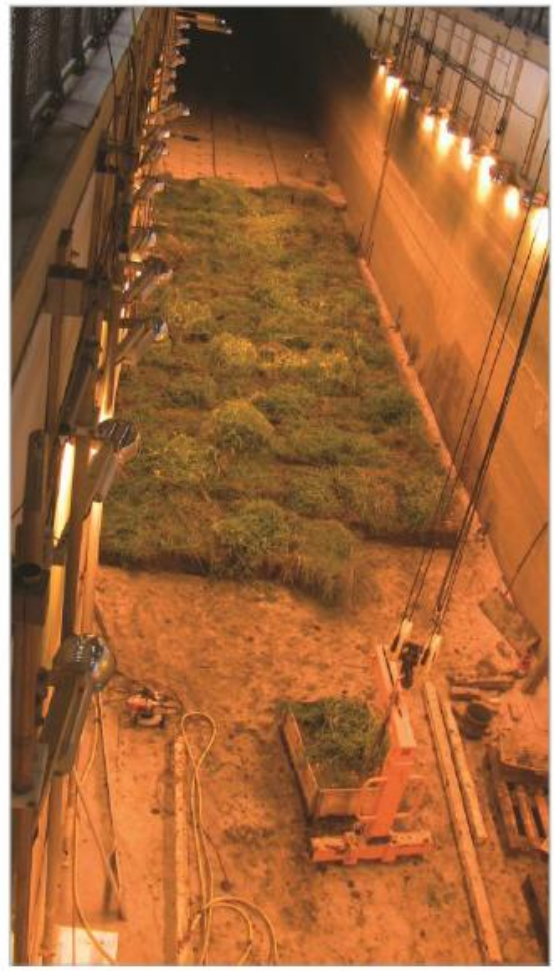

Figure 1: A: Experimental test-section in the Large Wave Flume (Grosser Wellenkanal, GWK) showing platform positions (1-6) for surface elevation measurements; B: view of the vegetated test section at the mid-point in construction, (see text for details), looking towards the wave paddle (photo: I Möller) 

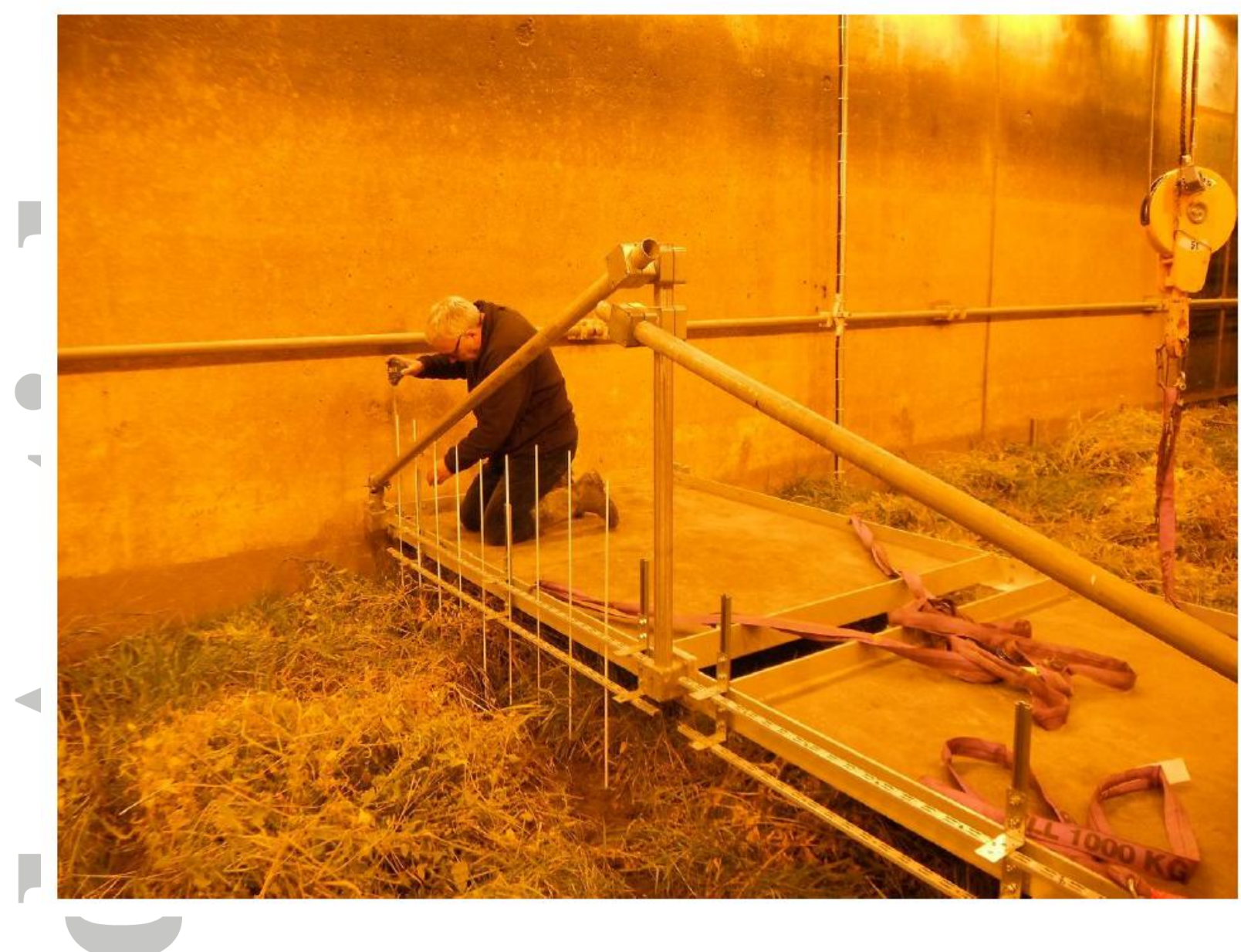

Figure 2: Cross-flume measurement of marsh surface elevation with first 9 pins of pin array deployed from temporary platform keyed into sidewall benchmarks (photo: I

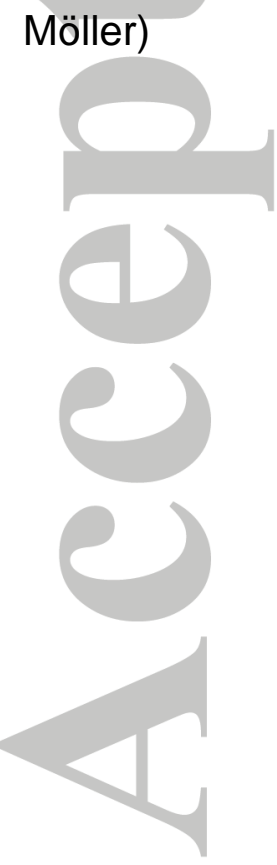

This article is protected by copyright. All rights reserved. 


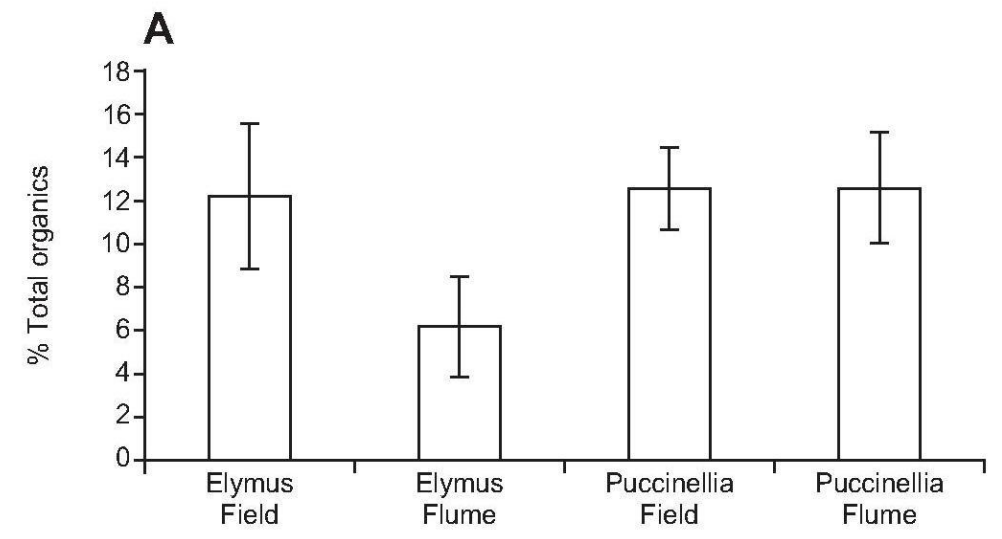

B
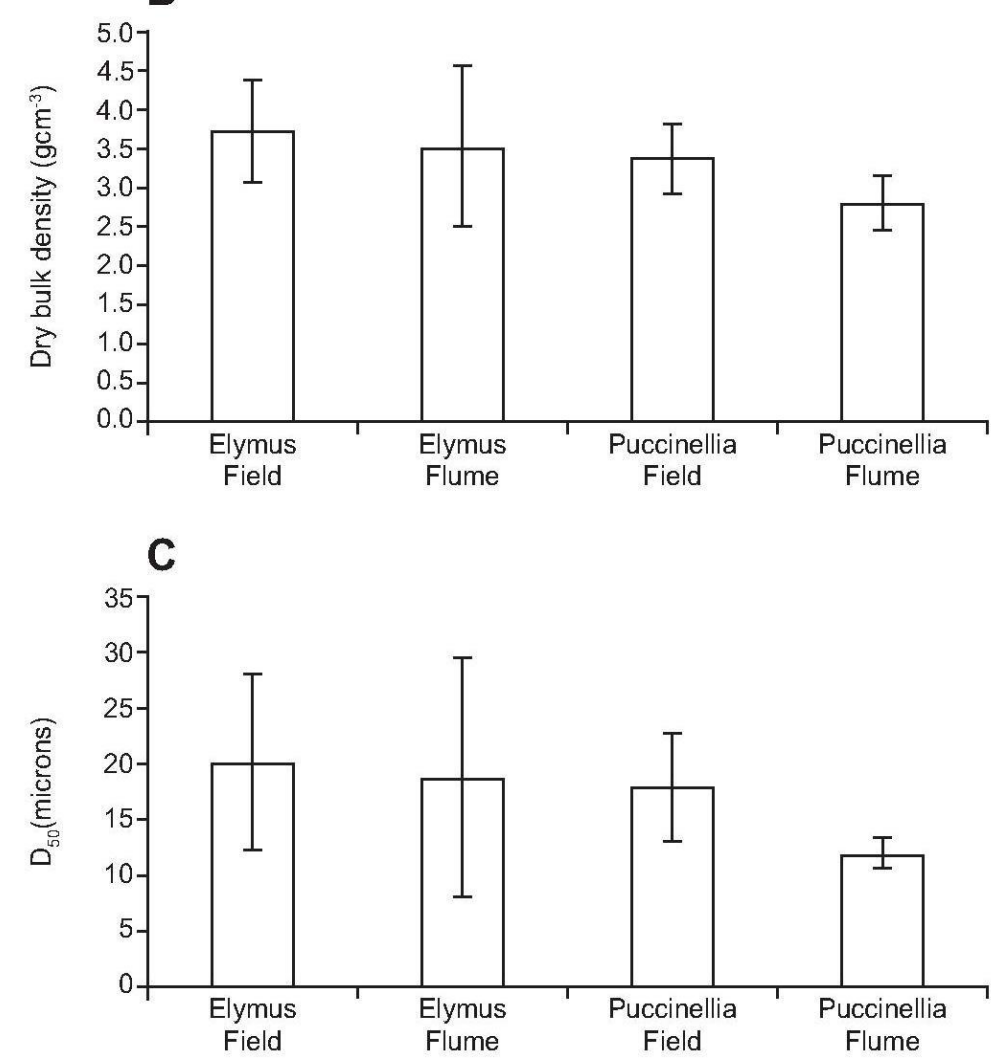

Figure 3: (a) Percentage organic matter, (b) bulk density, and (c) median grain size $\left(D_{50}\right)+$ - one standard error for the two dominant species, Puccinellia and Elymus, used in the experiment, as measured adjacent to the excavation site in the field and in the marsh blocks immediately prior to placement in the flume. 


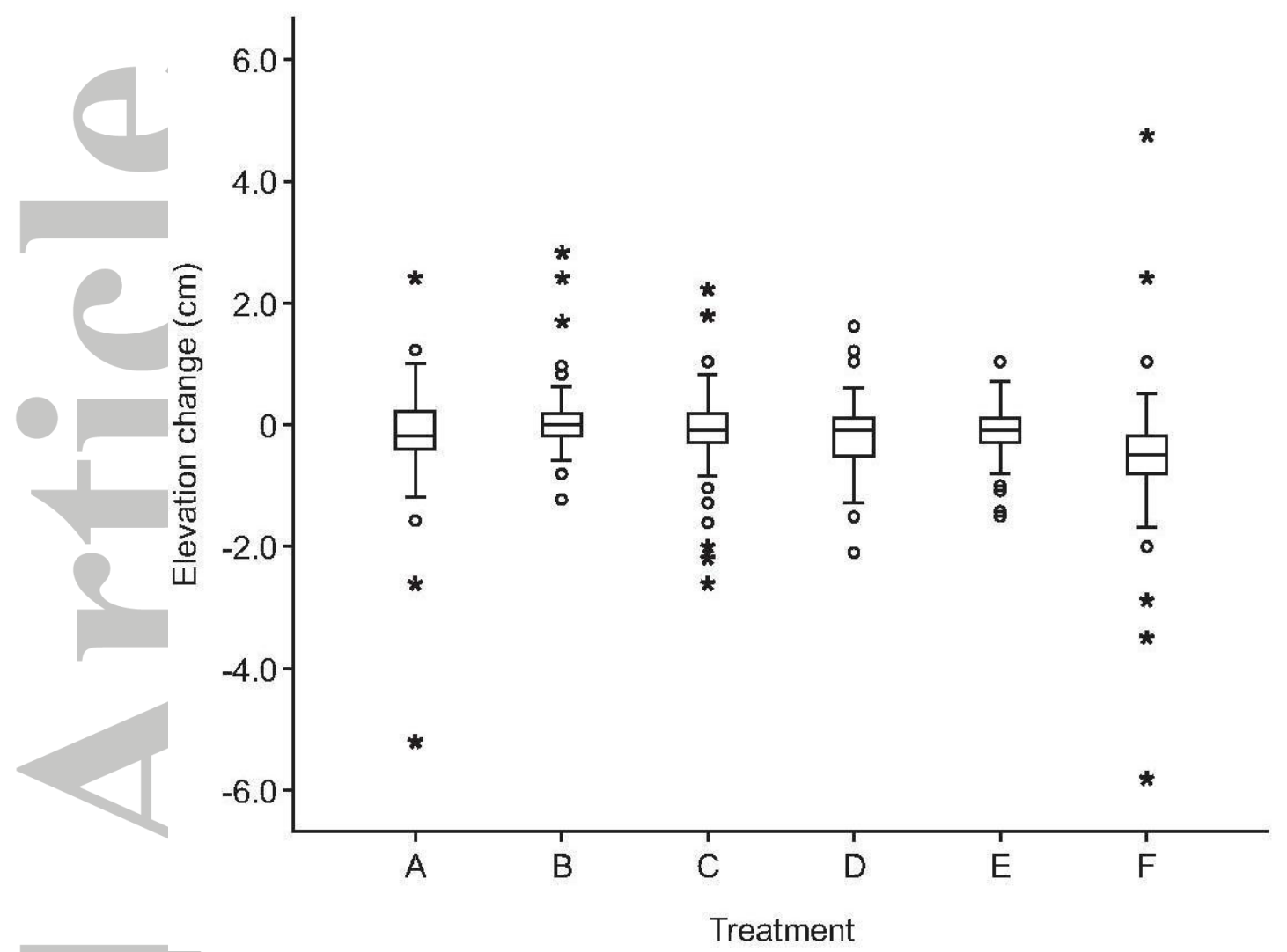

Figure 4: Summary box-plot showing median, inter-quartile range and standard errors of surface elevation change over the entire test section (i.e. aggregated for all six cross-flume transects (Figure 1) for the different treatments (A to E) and over all treatments $(\mathrm{F})$; outliers beyond 1.5 and 3.0 times the inter-quartile range are shown as circles and stars respectively. For wave run treatment details see Table 1. 


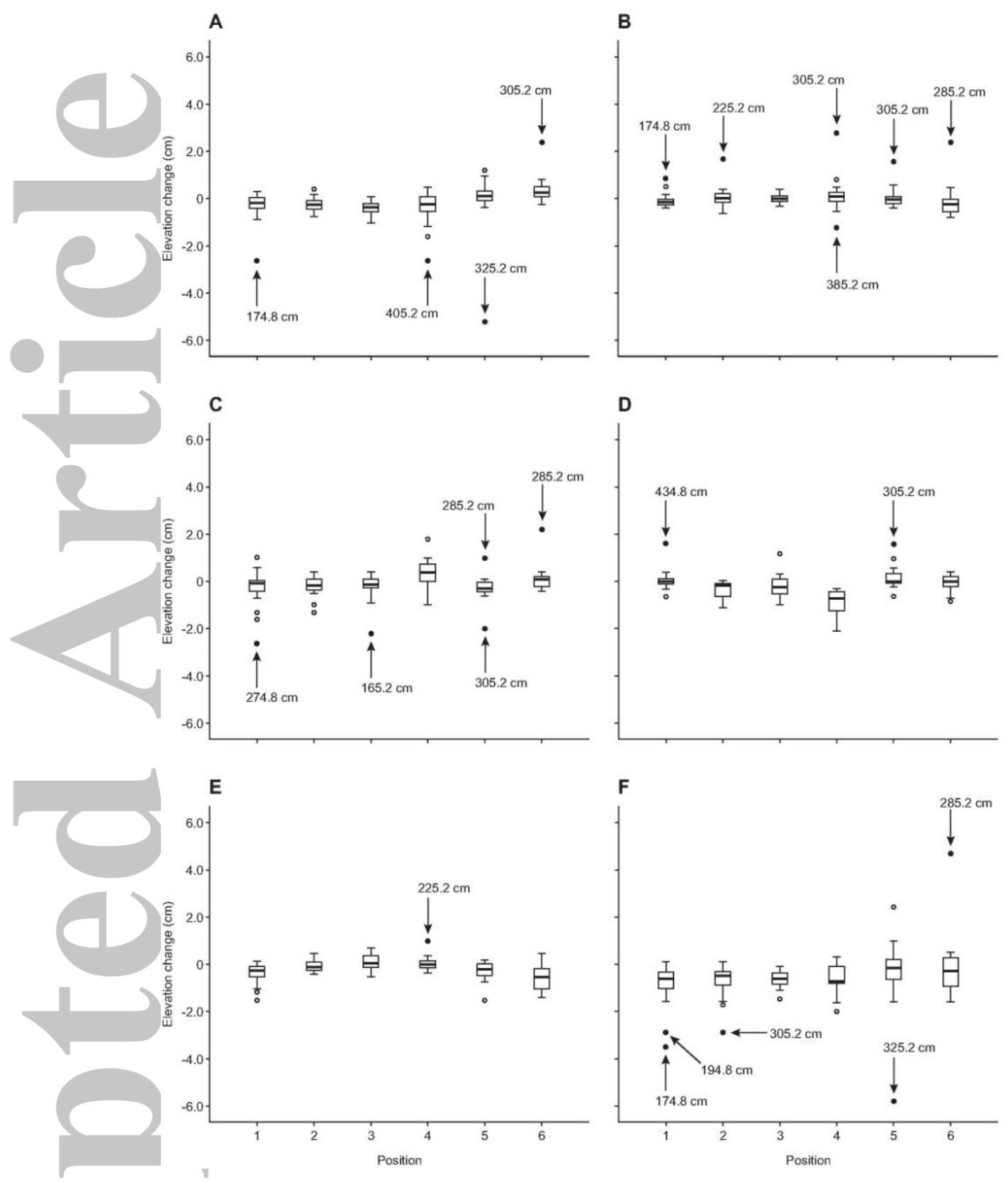

Figure 5: Elevation change $(\mathrm{cm})$ per platform position (see Figure 1 for positions 1-6) and successive treatments (median, inter-quartile range and standard errors): $A$ to $E$ treatment periods, with final plot (lower right) showing elevation change over all treatments $(\mathrm{F})$; outliers beyond 1.5 and 3.0 times the inter-quartile range are shown as open circles and solid circles respectively. For each of the latter, along-transect distances $(\mathrm{cm})$ from the south flume wall are indicated. For wave run treatment details see Table 1.

This article is protected by copyright. All rights reserved. 


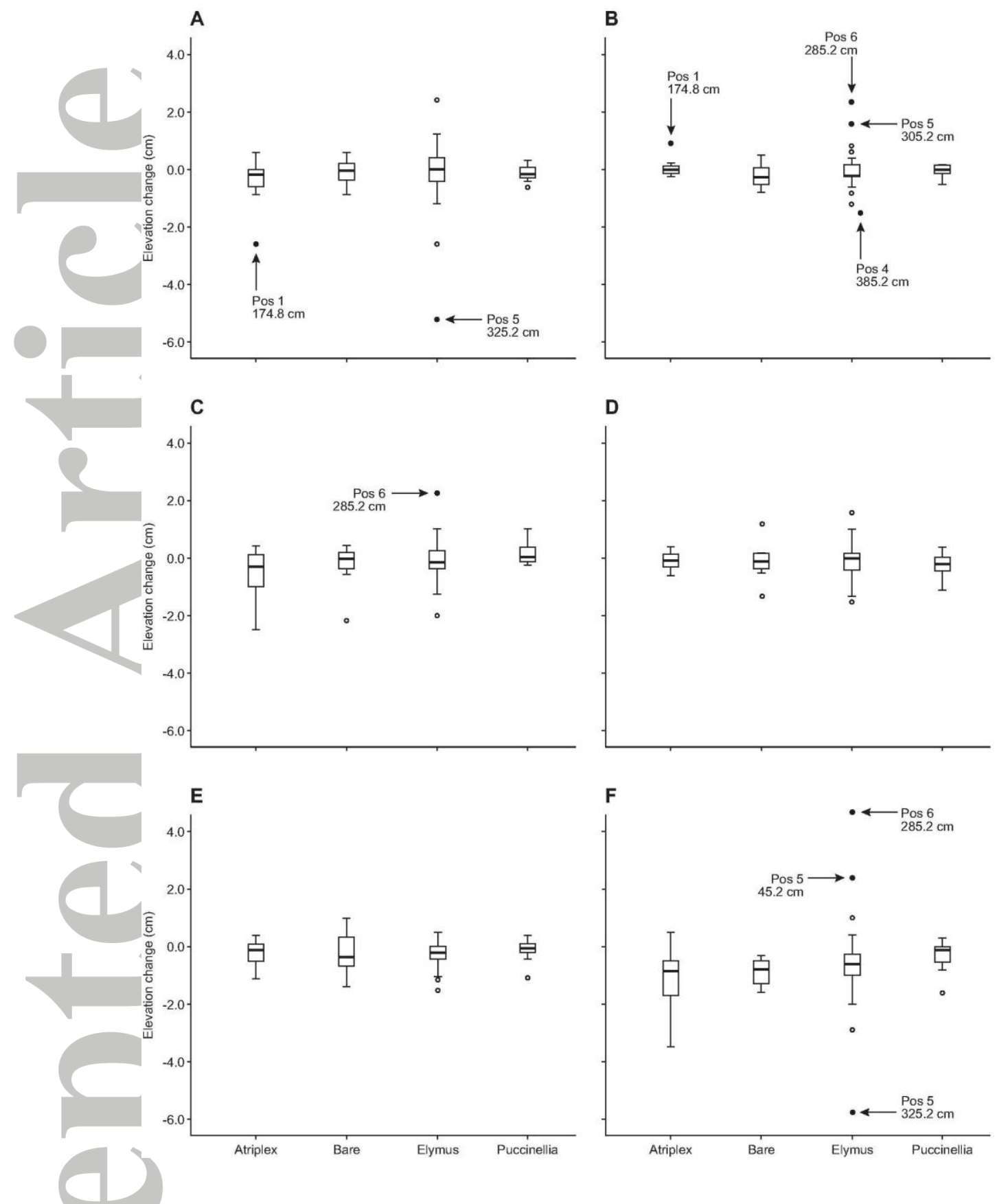

Figure 6: Elevation change $(\mathrm{cm})$ per surface type (median, inter-quartile range and standard errors) for each successive treatment: A to E wave run treatment periods (details in Table 1), with final plot (lower right) showing elevation change over all treatments $(F)$; outliers beyond 1.5 and 3.0 times the inter-quartile range are shown as open circles and solid circles respectively. For each of the latter, down-flume platform position number ('pos'; see Figure 1) and along-transect distances (cm) from the south flume wall are indicated.

This article is protected by copyright. All rights reserved. 